\title{
TRADITIONAL METHOD OF MUNG BEANS (VIGNA RADIATA) PRESERVATION USING PANCHAGAVYA AND ITS EFFECT ON SEED GERMINATION
}

\author{
Y. SWARNALATHA ${ }^{1 *}$, SIDDHARTHAN SEEMA ${ }^{2}$ \\ ${ }^{1}$ Department of Biotechnology, Sathyabama Institute of Science and Technology, Chennai, Tamil Nadu, India. ${ }^{2}$ Molecular and Nanomedicine \\ Research Unit, Centre for Nanoscience and Nanotechnology, Sathyabama University, Chennai, Tamil Nadu, India. Email: lokiswarna@gmail.com
}

Received: 22 February 2020, Revised and Accepted: 19 May 2020

\section{ABSTRACT:}

Objective: Callosobruchus chinensis is a major pest that affects mung bean causing severe damage during storage. The objective of the present study is aimed to evaluate the effect of panchagavya in larvicidal activity on $C$. chinensis and its seed germination was observed.

Methods: The methods used in this study were followed by observing the people at a remote village in Chittoor district of Andhra Pradesh. This study is about the traditional knowledge of the use of cow urine in panchagavya described in Ayurveda and its application in seed preservation.

Results: The ovicidal activity of panchagavya was remarkably good. The ability of ovicidal (instar) development into an adult beetle was found to be nothing. C. chinensis instar and adult beetle showed $100 \%$ mortality when treated with cow urine in small concentrations and good seed germination was observed.

Conclusion: Panchagavya is potentially effective and eco-friendly in controlling beetles in grains storage and its enhanced seed germination.

Keywords: Beetle, Cow urine, Instar, Mortality, Panchagavya.

(c) 2020 The Authors. Published by Innovare Academic Sciences Pvt Ltd. This is an open access article under the CC BY license (http://creativecommons. org/licenses/by/4. 0/) DOI: http://dx.doi.org/10.22159/ajpcr.2020.v13i8.37235

\section{INTRODUCTION}

The wide use of pesticides in the process of pest control during crop cultivation and seed preservation leads to environmental pollution and various health hazards [1]. The modern agriculture methods need to add millions of kilograms of pesticides every period. Unfortunately, their effect on non-target organisms is increasing day by day. Hence, traditional methods followed by ancient farmers are the best. These methods are not expensive as farmers use these materials which are locally available. In Sanskrit, panchagavya is a mixture of five products obtained from cow such as cow dung, cow urine, cow milk, curd, and ghee [2]. In panchagavya, cow urine is one of the important ingredients with high medicinal properties and capable of treating many diseases [3]. Cow urine is the best antifungal agent and an antibiotic; hence, cow urine kills a variety of germs and is a very good immune booster [4]. The constituent present in cow urine is water (95\%), urea $(2.5 \%)$, and a combination of compounds such as hormones, enzymes, minerals, and salts (2.5\%). There are studies on the effectiveness of cow urine as a bio-fertilizer and bio-pesticide [5]. The southern region of Rayalaseema in Andhra Pradesh includes four districts: Kurnool, Chittoor, Kadapa, and Anantapur. This study concentrates on Chittoor district, as around $70 \%$ of the lands are dry and the crops are rainfed type. Only 30\% is irrigated as against the Andhra Pradesh average (35\%). Among the pulses variety, red gram is the major variety, followed by green gram, black gram, horse gram, and cow gram. Most of the varieties of grams are raised in kharif season; however, some are cultivated in rabi season under irrigated and rainfed conditions. Pulses are cultivated as the main crop as well as an intercrop with groundnut in all mandals. The storage of seed plays an important role in the cultivation of crops, and this begins right at the time of attainment of physiological maturity of seeds in the field till it is planted in the next season. Hence, pulses need a proper method of storage condition without the use of any pesticides. Poor storage conditions lead to the growth of insects, rodents, and microorganisms, which may cause 30\% seed spoilage. The weather conditions during harvesting too affect the storage period, germination capacity, viability, and seed vigor. Hence, proper seed storage helps in appropriate germination and protection of seedlings in the early stage of growth. After harvesting and storage, ancient farmers followed various traditional methods of seed treatment such as Parashara's KrishiParashara, Surapala's Vrikshayurveda, Kautilya's Arthashastra, and Varahamihira's Brihat Jataka. These ideas are very unique to their area related to food culture. Most of the farmers at Chittoor district cultivate Mung bean (Vigna radiata), and Callosobruchus chinensis is a common pest affecting grains storage. Hence, the present study is aimed at assessing the effect of cow urine and hill soil in larvicidal activity on C. chinensis.

\section{METHODOLOGY}

Insect culturing

All the experiments in the present work were carried out in the Department of Biotechnology, Sathyabama Institute of Science and Technology, Chennai. C. chinensis L. beetles were obtained from a farmer at Gajulapalli village in Chittoor district. After collection, male and female beetles were observed and reared on clean, dry, and uninfested mung bean. Two jars with $300 \mathrm{~g}$ of mung bean were used, and 100 beetles were added in each jar. The jars were then covered and observed for the development of beetles.

Evaluating the effectiveness of the red soil and cow urine on C. chinensis L. larvae

Larvae of all the stages of $C$. chinensis $\mathrm{L}$. were gathered (first, second, third, and fourth instars) and served with $5 \mathrm{~g}$ of red soil and $2 \mathrm{ml}$ of cow urine. Ten grams of mung bean seeds were taken in four different jars and treated with $5 \mathrm{~g}$ of red soil and $2 \mathrm{ml}$ of cow urine. In each jar, 20 of the first, second, third, and fourth instars were introduced, and in all the instars, a negative control was set up without applying red soil and cow urine. Triplicates were used for all the instars and their control. The development of the larvae into adults and the mortality rate was recorded.

Effect of cow urine and red soil on adult beetle

Ten adults in each jar were taken, and $10 \mathrm{~g}$ of mung bean was added. One jar was maintained as control, and in another jar, the mung bean was treated with red soil and cow urine. Each group contained three 
replicates; after 5 days, the observations were recorded. The final count of eggs laid on the seed surface was noted. The percentage of mortality was determined.

\section{Seed germination}

The experiment was done using mung bean seeds. Control (fresh mung bean), seeds treated with panchagavya, untreated without panchagavya and the effect of seed germination was observed. Mung bean seeds were placed on one $5.5 \mathrm{~cm}$ Whatman No. 1 filter disk on a $5.5 \mathrm{~cm}$ absorbent pad in a $6 \mathrm{~cm}$ open Petri dish. Ten seeds were placed in Petri dish with distilled water-soaked tissue paper. All the plates were placed in a growth chamber with light and dark cycle $(16: 8 \mathrm{~h})$ at $25^{\circ} \mathrm{C}$. Distilled water was used for maintain moisture in the Petri dishes. Seed germination was recorded at different time periods such as $24 \mathrm{~h}, 48 \mathrm{~h}$, $72 \mathrm{~h}$, and $96 \mathrm{~h}$.

\section{RESULTS}

The illustration in Fig. 1 shows that cow urine and red soil are significantly effective with respect to the mortality and the development of adult beetles. Five $g$ of red soil and $2 \mathrm{ml}$ of cow urine are effective in the prevention of $C$. chinensis. However, in the untreated control mung bean, there was a significantly higher number of eggs than on cow urine and red soil treated seeds ( $p>0.05$ ). In the treated seeds, $100 \%$ mortality was recorded in all the stages of instar, which shows that none of the instars developed into adults (Fig. 1). The adult beetle mortality rate was also recorded as $100 \%$, which shows that none of the adults developed into

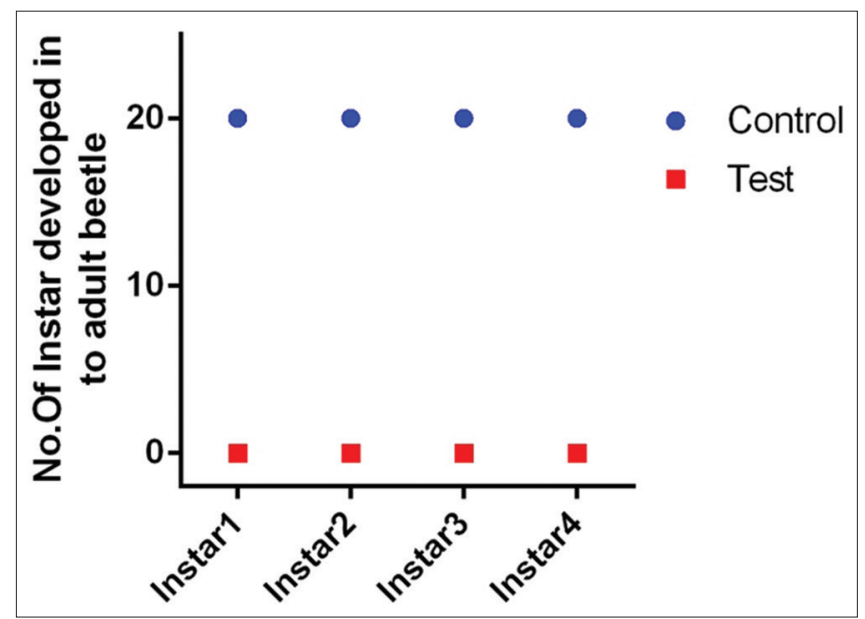

Fig. 1: Instar development in the red soil and cow urine treated red gram

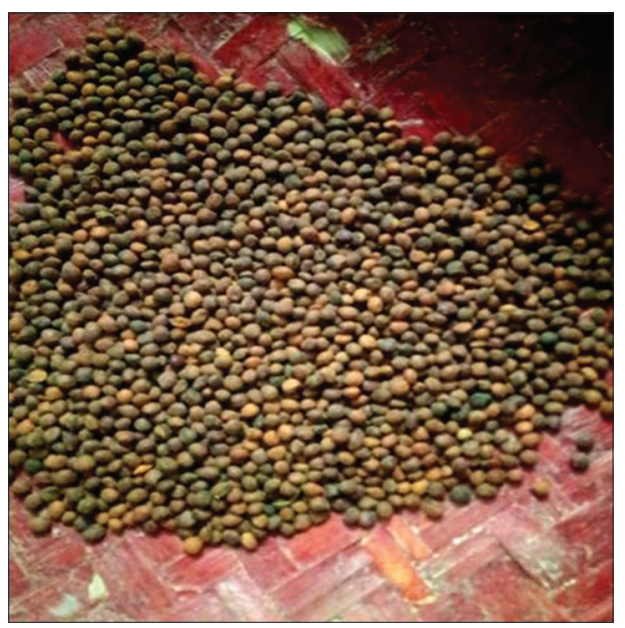

Fig. 2: Red soil and cow urine treated red gram stored for 6 months mung bean. Fig. 2 shows cow urine and red soil treated seeds preserved for 6 months (June-December 2017), which did not show any growth of C. chinensis. Hence, the current study proves that cow urine and red soil together can act as a best natural preservative for seeds.

\section{Storage of grains using mud pots soaked in cow urine}

Farmers in Chittoor district follow traditional storage methods for storing grains after harvesting. Storage of grains such as paddy and groundnut in mud pots for a longer time leads to the growth of storage pests. To prevent that, farmers close these mud pots with cow dung mixed with red soil and cow urine. Farmers use mud pots of various sizes and capacities, depending on the grain size. Especially before storage, the mung bean is treated with cow urine and red soil, then sundried to avoid fungal growth. Farmers place a ring, which is made of paddy straw on the floor, above that ring they keep the pots filled with grains, and the utmost pot is closed with red soil, cow dung, and cow urine (Figs. 3 and 4). The paddy straw soaked in cow urine inhibits the growth of the beetle and various insects. These seed materials are used to plant next year's crop. The grains can be stored in this method for more than 1year.

\section{Seed germination}

The seed germination ability of mung beans was analyzed by soaking the seed in panchagavya. Germination ability in the seeds treated with panchagavya, untreated, and control was observed at different time periods such as $24 \mathrm{~h}, 48 \mathrm{~h}, 72 \mathrm{~h}$, and $96 \mathrm{~h}$ (Fig. $5 \mathrm{a}$-d). Treated and control seeds showed good germination and growth compare to the untreated.

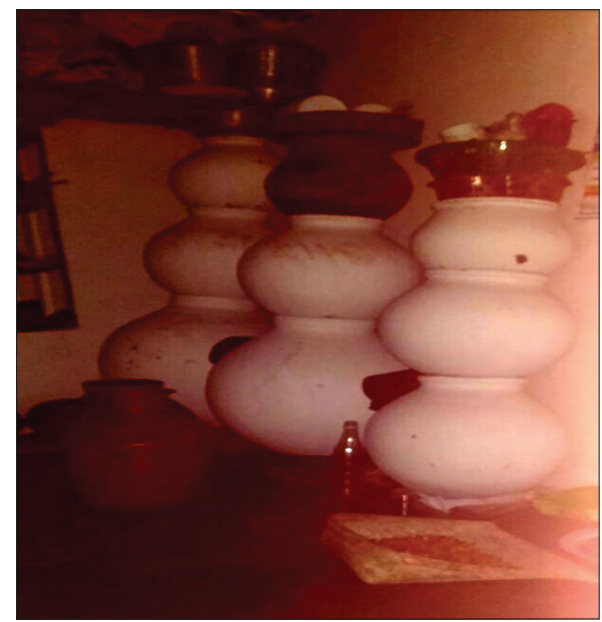

Fig. 3: Small storage pots coated with cow urine

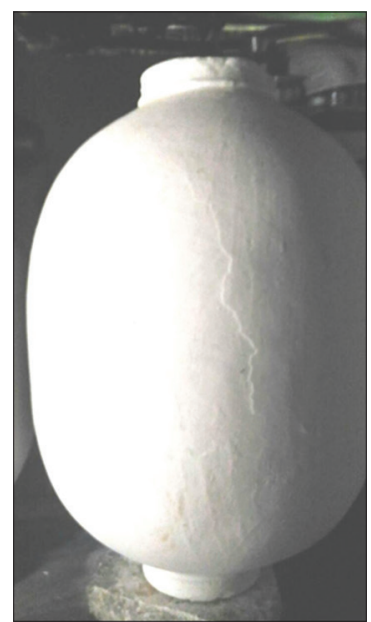

Fig. 4: Large storage mud pot coated with cow urine 

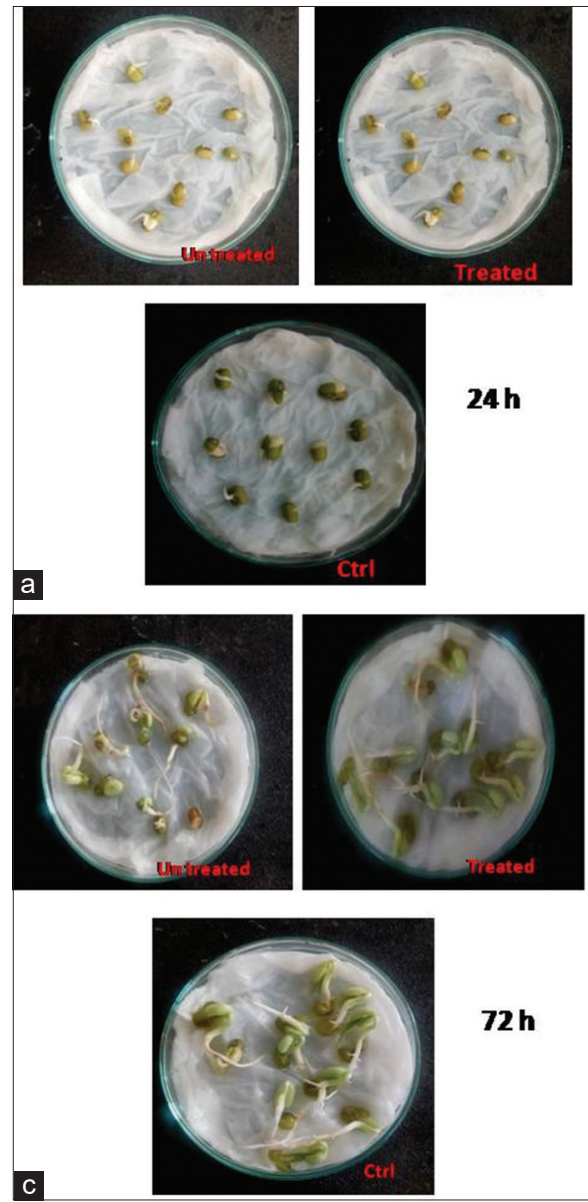

$\mathbf{2 4 h}$

$72 \mathrm{~h}$
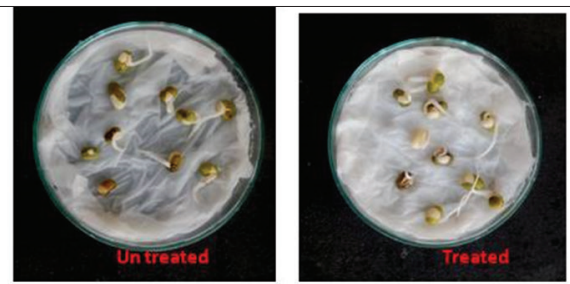

b

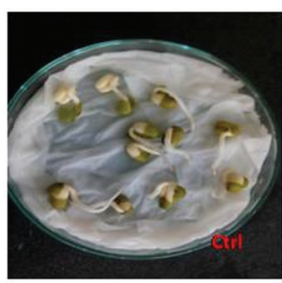

$48 \mathrm{~h}$
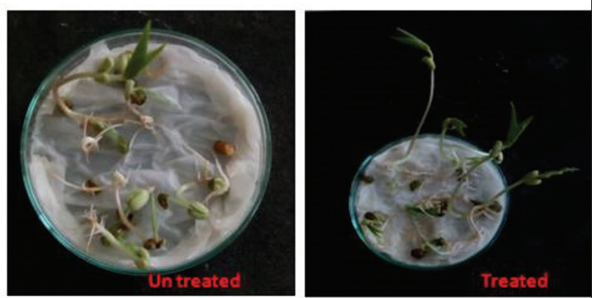

d

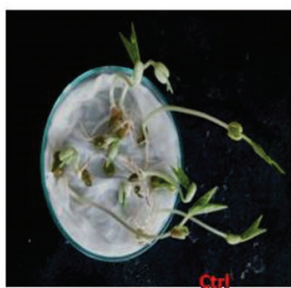

$96 \mathrm{~h}$

Fig. 5: (a-d) Seed germination

\section{DISCUSSION}

Panchagavya has different types of growth hormones such as ABA, IAA, and GA. [6]. This may be the reason of enhanced seed germination and also act as an effective pest repellent (instar). Results denote that cow urine and red soil seed dressing are very much efficient in reducing the growth of $C$. chinensis $\mathrm{L}$. larvae and adult. Ovicidal activity of cow urine showed a good reduction in the development of instar into adult beetle in a stored mung bean. Two milliliters of cow urine and $5 \mathrm{~g}$ of red soil are sufficient to cause $100 \%$ mortality in instar and inhibit the emergence of adult from instar. A study on the effectiveness of cow urine on dry beans to control Ootheca bennigseni pest led me to study the inhibitory activity of cow urine on $C$. chinensis $\mathrm{L}$ during mung bean storage. Cow urine can inhibit the abundance of $O$. bennigseni when sprayed for 7 days. Cow urine, the main ingredient in Panchagavya, is a plant growth promoter and has macro- and micro-nutrients, alcohols, fatty acids, alkanes, growth hormones, antibiotics, and metabolites [7]. Hence, cow urine acts as a good repellent to various pests, but these indigenous techniques are slowly disappearing all over the world. However, in Chittoor district of Andhra Pradesh, these methods are still followed by farmers and are easy and convenient for seed conservation for the next batch cropping season. Always indigenous methods are eco-friendly, effective, and less harm to nature and living beings. These eco-friendly pesticides, which are alternatives to the chemical and synthetic pesticides, can be used to preserve the genetic resources. Seed germination and seed growth quality properties were minimized with increasing concentration levels and time span with organic fortification which might be organic fortification that might be due to supra optimal dose of the organic product which is in general specific to crops [8]. Microbes and growth promoters in panchagavya enhanced the germination ability [9-11].

\section{CONCLUSION}

This study reveals that instead of using chemical pesticides to preserve the seed germ, cow urine can be used as a natural and effective preservative that has no toxic impact on human life. In this study, investigations of the seed germination and growth rates of mung bean were performed using panchagavya treated, untreated, and control. From the study, it was found that the effects of panchagavya treated samples increased seed germination and growth compared to the control and untreated samples. Panchagavya application is one of the traditional, eco-friendly and enhances the seed germination.

\section{ACKNOWLEDGMENTS}

The authors are thankful to the local farmers of Chittoor district for providing samples and cow urine and to Sathyabama Institute of Science and Technology for encouraging in conducting this research.

\section{AUTHORS' CONTRIBUTIONS}

All authors were contributed equally in this study.

\section{CONFLICTS OF INTEREST}

The authors declare that there are no conflicts of interest.

\section{FUNDING}

Nil.

\section{REFERENCES}

1. Noaishi MA, Afify MM, Allah AA. Study the inhalation exposure effect of pesticide mixture in the white rat. Nat Sci 2013;11:45-54. 
2. Sugha SK. Antifungal potential of panchagavya. Plant Dis Res Ludhiana 2005;20:156-8.

3. Pathak ML, Kumar A. Cow praising and importance of panchyagavya as medicine. Sachitra Ayurveda 2003;5:56-9.

4. Chauhan R, Singh BP, Singhal LK. Immunomodulation with Kamdhenu Ark in mice. J Immunol Immunopathol 2001;71:89-92.

5. Dharma K, Chauhan RS, Simmi T. Panchgavya (cowpathy): An overview. Int J Cow Sci 2005;1:1-15.

6. Chauhan JS, Tomar YK, Singh NI, Seema A, Delarati. Effect of growth hormones on seed germination and seedling growth of black gram and horse gram. J Am Sci 2009;5:79-84.

7. Somasundaram E, Amunullah MM. Panchagavya on organic growth and production of crops: A review. Green Farm 2007;1:22-5.

8. Henig-Severa N, Eshelb A, Ne'emana G. Regulation of the germination of Aleppo pine (Pinus halepensis) by nitrate, ammonium, and gibberellin, and its role in post-fire forest regeneration. Physiol Plant 2000;108:390-39.

9. Bhatnagar RS. Neem cake in disease control. Indian J Plant Pathol 1993;23:186-8.

10. Saritha M. Influence of selected organic manures on the seed germination and seedling growth of cluster bean. Sci Technol Arts RCSJ 2013;2:16-21.

11. Srimathi P, Mariappan N, Sundaramoorthy L. Efficacy of panchagavya on seed invigoration of biofuel crops. Acad J 2013;8:2031-7. 